\title{
POLISH - ROMANIAN MILITARY COOPERATION
}

\author{
Tomasz BĄK \\ Instytut Analizy Ryzyka Wyższa Szkoła Informatyki i Zarządzania w Rzeszowie \\ tbak@wsiz.rzeszow.pl
}

\begin{abstract}
Reborn after WWI, Poland needed to secure its borders properly against a potential enemy. As a result of the undertaken negotiations, the state strengthened the protection of its eastern border with a Polish-Romanian alliance. Before WWII, Romania was an important ally of Poland in the region and the only neighbour with whom Poland had a good relationship. Currently, both states are members of the EU and NATO, and their interests in security converge, especially in the face of deteriorating security in Eastern Europe. Closer military cooperation is also favoured by extensive political contacts and increasing expenditure on defence in both those states. In fact, Romania may well become the main ally of our country in the region within the next few years. [1]
\end{abstract}

Keywords: cooperation, military cooperation, Polish-Romanian alliance.

\section{Introduction}

\section{Military cooperation of Poland and} Romania before WWII

After the First World War ended, Polish diplomacy faced the difficult challenge of ensuring strong borders of the reborn state. Another objective was to define the place of Poland in Central and Eastern Europe anew. The planned system was supposed to be based on an alliance of Poland, Romania and Hungary. Yet an alliance treaty between Hungary and Romania could hardly be expected at a time when Hungary still held e.g. the annexation of Transylvania against Romania.

After Poland signed a peace treaty with Soviet Russia in October 1920, Bucharest's fears of aggression from the East intensified. It was considered highly likely that Soviet troops would be used against Romania in the nearest future. That threat caused higher interest of Romanian diplomacy in closer relations with Poland.
In autumn of that same year, the Romanian minister of foreign affairs contacted the Polish government with a direct proposal of cooperation within the Little Entente. Yet the mission met with a full fiasco, as it would mean the need for Poland's cooperation also with the Czechoslovakian diplomacy. At that time, Polish diplomacy were not fond of Czechoslovakia due to e.g. the trouble with Cieszyn Silesia. Thus the first attempt at Polish-Romanian agreement failed.

Yet Romanian diplomacy did not surrender the idea. Expansion from the East was becoming an ever growing danger for the state. In that situation, the issue of an agreement with Poland was revived, and Warsaw also wanted to benefit from the favourable circumstances in the desire to ensure Poland's eastern border for the future.

By the end of November, the Polish minister of foreign affairs started 
developing a draft of the alliance treaty. The draft provided for a Polish-Romanian alliance which would include political, military and trade agreements and a confidential protocol.

The political agreement was supposed to guarantee integrity of the eastern borders, geographically separate for Poland and Romania. Both states agreed to provide immediate military assistance to the respective ally if the border were violated by a "foreign military force". The scope of assistance was to be defined in a separate agreement. A three-year validity period was planned for the political treaty. The treaty was to be public, ratified and officially submitted to the secretary of the League of Nations.

The military agreement was meant to specify the principles of military cooperation between the allies, and a detailed scope of the potential mutual assistance. The issue of a trade agreement was not closely specified except for a plan to have it signed at a later time. The confidential protocol assumed a confirmation of border integrity between the allies and neutralisation of any attempt of Eastern Galicia to separate or become independent.

Conclusion of the negotiations was delayed by the fact that Romanians feared PolishHungarian friendship, which in their view could be harmful to Romania in the future. The pace of the negotiations was also slowed down by a note from Russia which reassured Romania of Russia's peaceful intentions towards the state. Romanians also feared the possibility of being included in the ongoing Polish-Soviet war. They were afraid that once they signed the treaties, their new ally might take further military actions.

The Romanian side suggested adding an article to the public part of the treaty stating that Romania could conclude separate agreements, which could later evolve into alliance treaties. The confidential protocol would also have an additional provision binding both Poland and Romania, concerning the transformation of the defensive alliance against Russia into a general one, aimed also against Germany. The Polish side, on the other hand, feared that it would be involved in a potential Balkan conflict against its will. Both Romania and Poland were afraid that the alliance might cause more harm than good, engaging them into an unplanned war against their will.

In January 1921, Polish diplomats presented a detailed project of a military convention, which included e.g. the obligation of both sides to a joint defence against Russian attack, regardless of its systemic form, and to providing ca. 85000 soldiers by both allies (fourteen infantry divisions and two cavalry ones) if the need arise. Final provisions obliged both parties to jointly conclude truces or peace treaties. The convention was initialled (not signed) by both parties.

The thus developed convention was to some extent useless, since each ally could, in fact, evade providing actual military assistance at any time.

On conclusion of the talks between military agents, it was time to develop a suitable political agreement and adjust it to the convention. The Romanian side issued a statement to the effect that it was consciously striving towards an alliance with Poland, but wished to have no relations with Hungary or Bulgaria. Both states took steps to obtain support for the agreement from France and Great Britain. France expressed a favourable stand in the matter, as it saw the future alliance as complementing the Polish-French one. The two allies were apprehensive of the reaction of British politicians, but that obstacle was also lifted.

However, the Polish government was not in a hurry to conclude the matter, because signing a Polish-Romanian alliance during peace talks with the Bolsheviks could cause serious complications at the negotiation table. On the other hand, they also waited 
for conclusion of an alliance with France, which would strengthen Poland's position in talks with Romania. The allies-to-be also preferred to wait for the right moment to conclude the treaty. Polish-Soviet negotiations came to a deadlock, and rumours from Warsaw brought news of a planned offensive. Signing an alliance at such a moment could result in immediate engagement of the Romanian army in the maelstrom of military actions.

Finally, on $19^{\text {th }}$ February the negotiations and settlements concerning the military convention came to a close. An obligation was written into the political agreement to have war declared by the respective party if its ally was attacked, and to jointly conclude truces and peace treaties. A provision was also included that the alliance would be ratified by Poland only after the negotiations in Riga were concluded and a peace treaty signed, yet it would be effective from the moment of signing in Bucharest. Signing a trade treaty was also planned, but it was not a priority to the Polish government, hence the matter was postponed.

Finally, the Convention on a Defence Alliance Between the Republic of Poland and the Kingdom of Romania was signed on $3^{\text {rd }}$ March 1921. The final version of the military convention was signed on the same day.

The convention on a defence alliance consisted of eight articles and three confidential protocols. They obliged the allies e.g. to provide mutual help in the case of an attack from the eastern borders. The convention established the obligation for communication in the matters of foreign affairs and relations with eastern neighbours. The effectiveness of the treaty was set for five years, and the partners were obliged to communicate in matters of concluding further alliances. That did not concern treaties already in existence or under negotiations. As stated above, the treaty included three confidential protocols with detailed arrangements. The military convention, signed on the same day, held no major differences from the one initialled on $29^{\text {th }}$ January. It consisted of 11 paragraphs which defined e.g. specific times for mobilisation and assumed joint actions of the staffs of both armies in mobilisation conditions.

Thus the several-month-long negotiations brought results in the shape of a PolishRomanian alliance which was to ensure the protection of our eastern borders.

After five years since the treaty was first effective, both sides signed a "guarantee contract" with a military annex named "arrangements techniques" in 1926. [2] An important political change as compared to the convention of 1921 was the obligation of mutual defence in the case of any attack, and not just one from the East. The military part of the treaty assumed that the other party would actively and automatically join the war only in the case of an attack from the East. On $15^{\text {th }}$ January 1931, the political convention was prolonged without any major changes to the content. The modified arrangements techniques were signed in June 1931, specifying mutual obligations. They provided e.g. for joining the war in the case of an attack on the eastern border of one or both states, even in the case of previous engagement in a conflict with a different enemy, and if the attacker was other than the USSR, the parties were obliged to provide aid to the attacked partner in the area of supplies, transport and transit. The agreement was to remain in effect for five years and be automatically prolonged if not previously terminated; thus 1936 saw an automatic prolongation.

The resumed Polish-Romanian inter-staff conferences continued joint operational studies, work on the issues of material cooperation, unification of armament and equipment, matters of transport, transit, etc. The allies also cooperated within intelligence, and the Polish arms industry placed serious deliveries of military equipment in the market of the Romanian partner. In 1932, Romania decided to purchase several dozen of P-11 aircrafts 
from PZL (Polish State Aviation Works), and in 1935 a contract was signed for the sale of Polish gas masks to that country. [3] The treaties were automatically prolonged for another five-year period in 1936. In a practical dimension, both governments endeavoured e.g. to coordinate development plans for military forces and principles of operational cooperation. [4] Due to a highly unfavourable development of the situation in Europe in the 1930s, the interwar PolishRomanian alliance was mainly of a symbolic significance. Both states were too weak, both in a political and in a military sense, for their cooperation to stop the German and Soviet aggression in 1939.

On 6 IX 1939, Romania officially declared neutrality in the new conflict, although it agreed to the transit of military equipment supplies to Poland through Romanian territory. On $17^{\text {th }}$ September, faced with USSR aggression, the Polish minister of foreign affairs released the Romanian side from the alliance obligations in the name of the Polish government, hoping Romania would grant right of way to the Polish authorities on their way West. Yet on crossing the Romanian border, Polish government members were interned. Bucharest did not accredit its representative for Gen. Władysław Sikorski's Polish government in exile formed in France, but it allowed the activity of Polish diplomatic and consular posts in Romania. That state held until 4 XI 1940, when the posts were closed at the demand of the Romanian authorities. That equalled breaking off any official relations between the former allies.

\section{Military cooperation of Poland and Romania after WWII until 1999}

After the Second World War, cooperation between Poland and Romania (including the military area) was established by signing the Treaty on Friendship, Cooperation and Mutual Assistance between the Republic of Poland and the People's Republic of Romania. It became effective on 29 XI 1949 and was binding for 20 years. It had an automatic five-year prolongation provision.

After the war, both states were under the USSR sphere of influence and became members of the Warsaw Pact in 1955. The Treaty on Friendship, Cooperation and Mutual Assistance between the People's Republic of Albania, People's Republic of Bulgaria, People's Republic of Hungary, German Democratic Republic, People's Republic of Poland, People's Republic of Romania, the Union of Soviet Socialist Republics and the Republic of Czechoslovakia became the basis for military cooperation of Poland and Romania.

On $12^{\text {th }}$ November 1970 , another Treaty on Friendship, Cooperation and Mutual Assistance was signed. It became effective on 15 III 1971. The treaty stated among others that in the case of armed attack against one of the High Contracting Parties from any state or groups of states, the other High Contracting Party would immediately provide assistance with any and all means it had at its disposal, including military assistance, as necessary to repel the armed attack.

\section{Military cooperation of Poland and Romania after NATO accession}

Currently, Poland and Romania develop their military cooperation, especially within their membership in NATO. Just like Poland, Romania has for many years supported American initiatives and actively participated in them in military and diplomatic areas, which naturally brings the two states closer. After the fall of the USSR and regaining sovereignty by the former communist states, Poland and Romania developed mainly economic cooperation based on the treaty on friendly relations and cooperation, signed on $25^{\text {th }}$ January 1993. Cooperation within defence was regulated by an agreement on cooperation within the military area.

Only in the 2010s, after their accession to NATO (Poland in 1999, Romania in 2004) 
and the European Union (Poland in 2004, Romania in 2007), the two countries began to see the potential for cooperation within security, including defence. High similarity of positions in security issues was conducive to deepening the cooperation. That results to a large extent from a similar strategic environment (Russia as a neighbour), historical experiences, energy determinants (dependence on the supply of Russian raw materials) and the need to catch up economically with the western EU states. Both states see their membership in NATO as the main outer pillar of their national security. Both view the role of the Alliance mainly in the context of collective defence. Both Poland and Romania strive to ensure that NATO retains the ability for defence operations based on art. 5 of the Washington treaty, which has gained particular significance now, after Russian aggression against Ukraine. The cooperation between the two states is based among others on a strategic partnership.

A declaration to that effect was signed by the presidents of Poland and Romania [5] on $7^{\text {th }}$ October 2009, and the action plan [6] was approved by representatives of the Ministry of Foreign Affairs during a visit of the Polish president on $26^{\text {th }}$ October 2010. The declaration states e.g. that "the main aim is to adjust NATO to new abilities and missions in the area of the Atlantic and globally, as well as to enhance the political, military and economic role of the European Union in areas of common interest" [7]. The cooperation is based on the Agreement between the Polish government and the Romanian government on bilateral defence cooperation, signed by the Polish minister of national defence and the Romanian minister of defence on $5^{\text {th }}$ June 2013. It replaced the previous agreement of 1994, concluded years before either state's accession to NATO, as the provisions of that agreement did not quite agree with the legal basis of NATO as concerned bilateral cooperation between its members. [8] Current political contacts of Polish and
Romanian authorities are very intensive. The political cooperation forms a good basis to develop bilateral defence cooperation. The cooperation of the two states within NATO is based on a common position in key issues related to NATO activities. Poland and Romania are mainly interested in maintaining the defensive nature of NATO, and in the face of Russia's aggressive actions, in maximum enhancement of collective defence abilities based on art. 5 of the Washington treaty and strengthening the eastern flank of the Alliance. At the Newport summit, Romania was Poland's main regional ally who made endeavours for the Alliance to adapt strategically to the new situation concerning security in the East of Europe. Very helpful in developing a common position was the eastern flank summit organised by the Polish president, Bronisław Komorowski, on $22^{\text {nd }}$ July 2014 in Warsaw. The participants included the presidents of Poland, Estonia, Lithuania, Latvia, the Czech Republic, Slovakia, Hungary, Romania and Bulgaria.

An example of mutual support within NATO may be the fact that in 2008 Romania delegated 2 officers to work with the Multinational Corps Northeast in Szczecin. [9] It also joined the NATO Military Police Centre of Excellence in Bydgoszcz. The Polish army, in turn, have one person in HUMINT COE (Human Intelligence Centre of Excellence) [10] in Oradea, Romania. Poland and Romania actively participate in NATO's programmes and activities. Both states joined the AWACS programme (Poland in 2008, Romania in 2011), which is the aerial component of the of NATO's early warning system. Allied reconnaissance aircrafts regularly use Polish airspace for reconnaissance flights, they may use the airport in Powidz, and 6 Polish soldiers work in the structures of the NAEW\&C Programme Management Organisation (NAPMO). [11] Also, along with 13 other NATO members, both states participate in 
the Alliance Ground Surveillance (AGS) programme, which is planned to be fully operational by 2017 [12], and the Strategic Airlift Capability (SAC) programme, the result of which was the establishment of a unit of $3 \mathrm{C}-17$ aircrafts stationed in the Papa base in Hungary. [13]

The construction programme for the European Phased Adaptive Approach (EPAA) announced in 2009 provided for four stages of its implementation. Within the programme, the United States decided to build two land bases with SM-3 missile launchers in Romania (by 2015) and in Poland (2018).

Since 2010, the ministries of defence of Poland and Romania hold expert consultations concerning BMD (Ballistic Missile Defence). The consultations are a forum for exchanging experiences, mainly in connection with the legal aspects of cooperation with the US in that matter, as well as work on a holistic system of NATO missile defence. Several sessions of talks took place within that format. Romania could also potentially be interested in purchasing modern air protection systems, considering the fact of Poland implementing the programme "Shield of Poland"; Poland gaining such abilities within the programme could open a new potential area of cooperation development.

\section{Scientific, industrial and technical cooperation}

The Romanian arms industry is the second biggest in Central and Eastern Europe, and it has similar problems as the same industry in Poland. Despite that, military repair and production companies as well as research institutes supervised by the ministries of defence do not use the cooperation potential. A step in the right direction was reactivating the Polish-Romanian Mixed Commission for Military and Technical Cooperation in November 2013, after 16 years. [14] The Commission's sessions took place when the Romanian secretary of the state for armament visited Poland on $19^{\text {th }}$ $20^{\text {th }}$ November 2013. The issues discussed during the meeting included topics related to the progress of technical modernisation in Polish and Romanian armed forces, implementing the adopted armament programmes and current cooperation. The Romanian delegation also visited the Polish Defence Holding (PHO Sp. z o. o.), Polish Chamber of National Defence Manufacturers (PIPnROK) and WB Electronics S.A. [15] In September 2011, BUMAR (currently Polish Defence Holding Sp. $\mathrm{z}$ o.o.) and the Romanian company UTI signed a contract for cooperation within security systems, software for crisis management integration systems, border and military facilities' protection and security, integrated solutions for critical infrastructure (including power facilities), transport, petroleum mining, power and gas networks, as well as joint R\&D activities. Another element of cooperation were issues connected with missile defence. The contract also covered a range of non-military areas and collaboration in third markets. [16] Moreover, PIPnROK holds talks with its Romanian counterpart (Asociatiei patronale romane a producatorilor de tehnica militarapatromil, PATROMIL) on industrial cooperation within air defence (a relevant agreement was concluded in 2012, and later specified in more detail in an annex signed in June 2013). PIPnROK stresses the purposefulness of synchronising the plans of the Polish and Romanian enterprises, opening a dialogue between users and producers in order to specify the initial equipment requirements, and starting bilateral discussions of military users in order to choose a common air defence ground system or its elements for both parties. [17]

\section{Conclusions}

Increasing the scope of military and diplomatic collaboration between Poland and Romania may help obtaining better conditions of joint alliances and initiatives. 
A closer military alliance with Romania may also facilitate talks with European countries which have different priorities in issues related to national security and EU security. [18]

Current Polish-Romanian relations within defence are characterised mainly by a high and still not fully used potential and growing dynamics. They have been developing intensively only since Romania accessed NATO in 2004, and gained more dynamics after establishing strategic partnership in 2009. The main areas of high potential for closer cooperation are issues related to negotiating positions concerning technological modernisation of the army and cyber defence (mainly in the area of strengthening defence abilities and the eastern flank) in NATO.

Due to the relatively broad powers of the presidents of both states within national security and defence issues, contacts between the state heads is a necessary element of good military relations.

Since 2011, contacts at the level of presidential advisors for national defence have developed very intensively.

The gradually increasing Romanian defence budget and ambitious modernisation projects will set the stage for closer bilateral cooperation, with air force being one of the potential areas. The Romanian government signing a contract of purchase of 12 used F16 aircrafts from Portugal (for 600 million euro) in October 2013 opened new possibilities in air force cooperation of Romania and Poland. [19] Poland, which has used F-16 for nearly 10 years, may be a useful partner for Romanian air forces regarding exercises and exchanging experiences in the use and maintenance of the machines. The purchase of F-16 crafts will thus be a good occasion for joint Polish-Romanian exercises (possibly together with the US), exchanging experiences in exploitation of the aircrafts and perhaps in limiting maintenance costs. Another perspective area is air defence, including missile defence, both in the context of NATO, cooperation with the USA and potential bilateral cooperation within building national defence abilities (of short and medium range). Both Poland and Romania still lack national abilities they could contribute to the NATO system, although Poland has started to build them, contrary to its ally. Currently, Romania's modernisation priority are multirole aircrafts (the purchase of F-16 and modernisation of their intended station in the air base in Fetești), but it is possible that the state will decide to modernise its air (and missile) defence system in the future, as the currently used post-Soviet S-75 M3 launchers and American MiM-23 Hawks were designed in the 1950s. The current contribution of Poland and Romania to NATO missile defence is their agreement to grant the use of the land to locate elements of the system. After activating both bases in Devesel (2015) and Redzików (2018), participation in the project will be a natural area for closer cooperation, which may include joint exercises, exchanging experiences in base functioning, as well as creating legal basis for the presence of the American forces in the particular state.

One of the growth areas in defence cooperation is cybersecurity. Due to the dynamic development of electronic systems in every area of defence, but also of economic and social life, ensuring security in cyberspace will be one of the major tasks for NATO states in the $21^{\text {st }}$ century. It is thus the more important to seek partners for cooperation and exchange of experiences, and Romania has much to offer in the area of cybersecurity. Romanian services which combat Internet dangers enjoy good reputation worldwide.

There are good grounds for the defence cooperation of Poland and Romania to develop more dynamically, especially in the practical aspect. First, the bilateral relations have a good, long history. The cooperation before WWII, even though it did not bring spectacular results, is still indicated as a positive example by both states. Second, 
Poland and Romania have a practically full correspondence of security interests, both as concerns NATO and the European Union. The existing small differences (the main ones being e.g. the attitude to Kosovo's independence, or promoting the Black Sea as a strategic direction by the Romanian government) currently lose their significance in the face of other, far more serious challenges for the flank states. Third, the recent years saw the development of political cooperation in a variety of formats and with numerous bilateral visits. It is high time now to fill the said formats with content. Fourth, the growing threat from Russia is an impulse to revitalise defence in Central and Eastern European countries. Poland and Romania both understand that NATO security guarantees do not exempt them from building national defence abilities and strengthening state resistance to aggression. They increase their defence budgets, which allows to modernise the army and helps cooperation. Fifth, it has recently turned out that the cohesion of the principal formats in which Poland invested, such as the Visegrád Group or Weimar Triangle, is questionable. The sharp security crisis in Europe caused an increase of other partners who share the Polish perception of threat to a greater degree. Those include Great Britain (particularly within NATO), Scandinavian countries (Sweden and Finland) and Romania. It is thus worth investing in defence relations (and more broadly - in security), both engaging in trilateral cooperation including Turkey, as suggested by the Romanian side, and engaging Romania in formats in which Poland is active. That would serve both to counterbalance tendencies disadvantageous to Poland (e.g. in the Visegrád Group), and to build a broader coalition within NATO or the EU in matters of interest.

The Ministry of National Defence expects that further bilateral contacts within defence cooperation will be connected with the following areas:
1. performing the obligations within security and defence as resulting from the membership of both discussed countries in NATO and the European Union;

2. projects aiming at NATO's military transformation;

3. cooperation of arms industries, in particular as regards modernising the armed forces and using the possibilities offered by the European Defence Agency;

4. consultations concerning the effectiveness of multilateral actions within combatting modern threats to the international security environment;

5. military and technical cooperation.

An important factor in shaping mutual relations between Poland and Romania within defence is the Polish-Romanian strategic dialogue, occurring since March 2011.

The catalogue of areas for future defence cooperation between Poland and Romania includes e.g.:

1. defence planning;

2. the functioning of the armed forces in modern democratic societies, including the application of provisions of international treaties on defence, security and arms control;

3. peace and humanitarian missions as well as other operations of international organisations concerning peace support and combatting terrorism;

4. organisation of the armed forces, including military unit structure and HR management policy;

5. logistic support for the needs of the armed forces;

6. military education system;

7. military personnel training;

8. activities within combat search and rescue (CSAR);

9. research within defence technology;

10. development, maintenance and repair of arms and military equipment;

11. modernisation and conversion of arms and military equipment;

12. military IT systems, information and communication technologies; 
13. normalisation, quality control and codification in the military;

14. military medicine and medical support;
15. law and economy within defence.

We are hopeful that the above will bring many tangible benefits for both states.

\section{References}

[1] Przemysław Pacuła - Polsko-rumuńska współpraca obronna. Stan obecny i perspektywy https://www.bbn.gov.pl/ftp/dok/03/35_KBN_PACULA.pdf [accessed: 09.03.2018];

[2] "Traktat gwarancyjny między Polską a Rumunją" (org. spelling), signed in Bucharest on $26^{\text {th }}$ March 1926 (Dz.U. 1927, No. 16, items 117 and 118), http://dziennikustaw.gov.pl/DU/1927/s/16/117 [accessed: 09.03.2018];

[3] "Konwencja o przymierzu odpornym między Rzeczpospolitą Polską a Królestwem Rumunii”, $\quad 3^{\text {rd }} \quad$ March 1921, http://konsulat-Romaniapoznan.republika.pl/14Dywizja/PolandRomania.htm [accessed: 09.03.2018];

[4] More at: Gen. W. Stachowicz, "Relacje o kampanii wrześniowej", copied of 1960 http://pism.co.uk/B/BI2ap2 1.pdf [accessed: 09.03.2018];

[5] Przemysław Pacuła. "Polsko-rumuńska współpraca obronna. Stan obecny i perspektywy" -https://www.bbn.gov.pl/ftp/dok/03/35_KBN_PACULA.pdf [accessed: 09.03.2018];

[6] The Action Plan assumes e.g. regular meetings of heads of diplomacy and experts, as well as cultural and economic collaboration;

[7] "[G]łównym celem jest dostosowanie NATO do nowych zdolności i misji w rejonie Atlantyku oraz na poziomie globalnym, jak również wzmocnienie politycznej, militarnej i ekonomicznej roli Unii Europejskiej w obszarach wspólnego zainteresowania";

[8] Polish-Romanian agreement on defence cooperation, Ministry of National Defence, $6^{\text {th }}$ June 2013, http://archiwalny.mon.gov.pl/en/artykul/14394 [accessed: 09.03.2018];

[9] Information from the Corps webpage: http://mncne.pl/thirteen-member-states-of-thecorps/ [accessed: 09.03.2018];

[10] NATO Humint Centre of Excellence, http://www.natohcoe.org [accessed: 09.03.2018];

[11] "Udział Polski w inicjatywach transformacyjnych NATO", information of the Ministry of National

Defence,http://www.archiwalny.mon.gov.pl/pliki/File/UDZIAL_POLSKI W INICJAT YWACH_TRANSFORMACYJNYCH_NATO_2011.pdf [accessed: 09.03.2018 r.];

[12] Progress on AGS with completion of first NATO-owned air vehicle, NATO information, $5^{\text {th }}$ June 2015, http://www.nato.int/cps/en/natohq/news 120429.htm [accessed: 09.03.2018];

[13] Strategic Airlift, NATO information, http://www.nato.int/cps/en/natohq/topics_50107.htm?selectedLocale=

en [accessed: 09.03.2018];

[14] The Commission was established in 1994 based on provisions of the agreement on military cooperation. The last session of the Commission took place in 1997 and concerned digital communication systems. The Commission ceased its activity in 1998 for reasons beyond Polish control. Its reactivation was discussed as late as March 2011;

[15] "Generał Catalin-Andre Moraru z wizytą w Polsce", information of the Ministry of National Defence, $19^{\text {th }} \quad$ November 2013 , http://mon.gov.pl/aktualnosci/artykul/najnowsze/2013-11-19-general-catalin-adrianmoraru-z-wizyta-w--polsce/ [accessed: 09.03.2018]; 
[16] "E-RAPORT MSPO 2/2011 - Romania Dołącza Do Tarczy Polska”, $8^{\text {th }}$ September 2011, http://www. altair.com.pl/mspo-report/view?article_id=343 [accessed: 09.03.2018];

[17] Kronika Wojska Polandego 2012 r., http://mon.gov.pl/z/pliki/dokumenty/rozne/2014/10/Kronika_2012.pdf [accessed: 09.03.2018 r.];

[18] Adam Burakowski - Na ile Romania może być partnerem Poland http://www.omp.org.pl/stareomp/index2cc4.html?module=subjects \&func=viewpage $\& p$ ageid=773 [accessed: 09.03.2018 r.];

[19] D. Donald, Romania finally settles on Portugese F-16, AINonline, 18 października 2015 r., http://www.ainonline.com/aviation-news/2013-10-18/romania-finally-settlesportuguese-f-16s [accessed: 09.03.2018 r.]. 